\title{
Standardization of Leaf Sampling Technique in Jackfruit Nutrient Status Diagnosis
}

\author{
Yan Sun 1,2,3, Jianfeng Yang1,2,3, Hua Wang1,2,3, Chao Zu ${ }^{1,2,3}$, Lehe Tan 1,2,3*, Gang Wu1,2,3 \\ ${ }^{1}$ Spice and Beverage Research Institute, Chinese Academy of Tropical Agricultural Sciences, Wanning, China \\ ${ }^{2}$ Key Laboratory of Genetic Resources Utilization of Spice and Beverage Crops, Ministry of Agriculture, \\ Wanning, China \\ ${ }^{3}$ Hainan Provincial Key Laboratory of Genetic Improvement and Quality Regulation for Tropical Spice and \\ Beverage Crops, Wanning, China \\ Email: thlh3687@163.com
}

Received 27 January 2015; accepted 9 February 2015; published 16 February 2015

Copyright (C) 2015 by authors and Scientific Research Publishing Inc.

This work is licensed under the Creative Commons Attribution International License (CC BY).

http://creativecommons.org/licenses/by/4.0/

(c) (i) Open Access

\begin{abstract}
In China, little information is known about the nutrient requirements of jackfruits and the traditional nutrient management usually depends on the experience. Therefore, in this study, an attempt was made to standardize the leaf sampling technique and the suitable range of leaf nutrient concentrations for jackfruit (Artocarpus heterophyllus Lam.) nutrient status diagnosis. The sampling result was affected by canopy height, leaf age and time of sampling. Therefore, the three factors were studied. The results illustrated that the stability in level of nutrient concentrations was in 3 - 6 month-old leaves from the central part of the canopy. The most stable period was from April to May for leaf sampling. It was recommended that the stable intra-canopy and stable period of nutrient concentrations could be used as the standards of leaf sampling technique. Based on the leaf sampling technique, the standard of leaf nutrient concentrations was summarized, and could be used as the standard of nutrient suitability evaluation.
\end{abstract}

\section{Keywords}

Jackfruit, Nutrient Status Diagnosis, Leaf Sampling Technique, Standardization

\section{Introduction}

The jackfruit is widely cultivated and popular fruit in tropical regions. In China, its planting area is about 10,000 hectares, of which is more than 5000 hectares in Hainan. Its fruit is the largest tree-borne fruit, and its growth

${ }^{*}$ Corresponding author.

How to cite this paper: Sun, Y., Yang, J.F., Wang, H., Zu, C., Tan, L.H. and Wu, G. (2015) Standardization of Leaf Sampling Technique in Jackfruit Nutrient Status Diagnosis. Agricultural Sciences, 6, 232-237.

http://dx.doi.org/10.4236/as.2015.62023 
consumes large amounts of nutrients from soil. However, little information is known about the nutrient requirements of jackfruits. For years, the leaf nutrient analysis is widely used for plant nutrient status diagnosis [1]-[6]. Comparison of the results of leaf analysis and the standard of leaf nutrient concentrations, the level of sufficiency or deficiency of plant nutrient status can be estimated, and as a result the optimum fertilization rate may be recommended [7] [8]. However, the value of leaf analysis depends on sampling technique, including canopy height, leaf age and time of sampling [9]-[13].

The sampling technique has been worked out in many fruiting plants, such as apple, pear, bael and lime [14]-[17]. However, there is still a dearth of the leaf sampling technique in jackfruit, and thus more data need to be provided. In this paper, through the field sampling and lab test, the canopy height, leaf age and time of sampling for jackfruit were determined. The purpose of this paper is to standardize the sampling technique of jackfruit, and recommend fertilizer.

\section{Materials and Methods}

\subsection{Site}

During 2011-2013, field experiments were performed at 8 high yielding orchards of jackfruit in Hainan, China. The sites are located in north latitude $18^{\circ} 9^{\prime}-20^{\circ} 11^{\prime}$, east longitude $108^{\circ} 21^{\prime}-111^{\circ} 03^{\prime}$ and altitude $1-1000 \mathrm{~m}$. The tropical climate is characterized by average annual temperature of $23^{\circ} \mathrm{C}-25^{\circ} \mathrm{C}$ and average annual rainfall of $1000-2000 \mathrm{~mm}$. The soil of the experimental orchards is latosol (sandy clay loam).

\subsection{Sampling}

The leaves were sampled on a population of 10 representative trees in each plot. The samples were collected between 8 and 10 AM from all four directions to avoid variation at the end of every month for one year, and the sampling period was from 2011 to 2013. The collected samples should be brought to the laboratory on the same day, and then they were washed in tap water and distilled water, respectively.

\subsection{Samples Analysis}

The analyses were carried out on dry leaf samples after grinding. The diacid $\left(\mathrm{H}_{2} \mathrm{SO}_{4}-\mathrm{H}_{2} \mathrm{O}_{2}\right)$ digests were used for determination of nitrogen $(\mathrm{N})$, phosphorus $(\mathrm{P})$, potassium $(\mathrm{K})$, calcium $(\mathrm{Ca})$, magnesium $(\mathrm{Mg})$, iron $(\mathrm{Fe})$, manganese $(\mathrm{Mn})$, copper $(\mathrm{Cu})$ and zinc $(\mathrm{Zn}) . \mathrm{N}$ was determined by the Kjeldahl digestion method. $\mathrm{P}$ was determined by Mo-Sb Anti spectrophotometric method. $\mathrm{K}$ was determined by flame photometer. $\mathrm{Ca}, \mathrm{Mg}, \mathrm{Fe}, \mathrm{Mn}, \mathrm{Cu}$ and Zn were determined by atomic absorption spectrophotometry. Sulfur (S) was determined by $\mathrm{BaCl}$ turbidimetry after acid $\left(\mathrm{HNO}_{3}-\mathrm{HClO}_{4}-\mathrm{HCl}\right)$ digestion method. Boron (B) was determined by azomethine- $\mathrm{H}$ spectrophotometric method [16] [18].

\subsection{Statistical Analysis}

The standard of leaf nutrient concentrations, which consist of deficient range, low range, optimum range, high range and excess range for each nutrient, has been derived using the mean and standard deviation of leaf nutrient concentrations. The optimum nutrient range was the values derived from "mean $-4 / 3 \mathrm{SD}$ (standard deviation) to mean $+4 / 3$ SD"; The low range was obtained by calculating "mean $-4 / 3$ SD to mean $-8 / 3$ SD" and the values below "mean - 8/3 SD" were considered as deficient range; The values from "mean + 4/3 SD to mean + 8/3 SD" were taken as high range and the values above "mean + 8/3 SD" were taken as excessive range [18].

All statistics were calculated using SPSS (version 19.0) statistical software.

\section{Results}

\subsection{Canopy Height and Leaf Age of Sampling}

As can be seen from the Table 1, besides Ca, Mn and B, the higher leaf nutrient concentrations are found from the lower canopy. The higher concentrations of N, P, K, Cu and $\mathrm{Zn}$ in the 3 - 6 month-old leaves are observed from the lower canopy; The higher concentration of Fe in the over 6 month-old leaves is found from the lower canopy. Compared with the over 6 month-old leaves, the N, P, K, Cu and $\mathrm{Zn}$ concentrations are higher in the 3 - 
Table 1. Effect of canopy height and age on jackfruit leaf nutrient concentrations.

\begin{tabular}{|c|c|c|c|c|c|c|c|}
\hline Nutrient & 1 & 2 & 3 & 4 & 5 & 6 & Mean \\
\hline N (\%) & 2.31 & 2.65 & 2.29 & 2.64 & 2.32 & 2.73 & 2.49 \\
\hline P (\%) & 0.15 & 0.21 & 0.15 & 0.21 & 0.15 & 0.21 & 0.18 \\
\hline K (\%) & 0.97 & 1.88 & 0.99 & 1.85 & 0.95 & 2.04 & 1.45 \\
\hline Сa (\%) & 1.41 & 1.01 & 1.38 & 1.01 & 1.38 & 0.93 & 1.19 \\
\hline $\operatorname{Mg}(\%)$ & 0.29 & 0.29 & 0.29 & 0.29 & 0.31 & 0.29 & 0.29 \\
\hline S (\%) & 0.23 & 0.22 & 0.22 & 0.22 & 0.22 & 0.23 & 0.22 \\
\hline $\mathrm{Fe}\left(\mathrm{mg} \cdot \mathrm{kg}^{-1}\right)$ & 90.26 & 91.97 & 94.43 & 95.92 & 106.52 & 93.58 & 95.45 \\
\hline $\operatorname{Mn}\left(\mathrm{mg} \cdot \mathrm{kg}^{-1}\right)$ & 530.28 & 421.48 & 523.17 & 427.05 & 522.68 & 359.54 & 464.03 \\
\hline $\mathrm{Cu}\left(\mathrm{mg} \cdot \mathrm{kg}^{-1}\right)$ & 6.77 & 13.37 & 7.21 & 12.78 & 7.03 & 14.82 & 10.33 \\
\hline $\mathrm{Zn}\left(\mathrm{mg} \cdot \mathrm{kg}^{-1}\right)$ & 29.83 & 33.77 & 28.90 & 33.94 & 30.74 & 33.98 & 31.86 \\
\hline $\mathrm{B}\left(\mathrm{mg} \cdot \mathrm{kg}^{-1}\right)$ & 39.59 & 34.22 & 41.73 & 35.00 & 40.30 & 35.14 & 37.66 \\
\hline
\end{tabular}

1: over 6 month-old leaves from the upper canopy; 2: 3 - 6 month-old leaves from the upper canopy; 3: over 6 month-old leaves from the central canopy; 4: 3 - 6 month-old leaves from the central canopy; 5: over 6 month-old leaves from the lower canopy; 6: 3 - 6 month-old leaves from the lower canopy.

6 month-old leaves, but the $\mathrm{Ca}, \mathrm{Mn}$ and B are lower. Mg and S levels are relatively constant in the plants. The results indicated that the stability of leaf nutrient concentrations in the jackfruit was in the 3 - 6 month-old leaves from the central canopy.

\subsection{Time of Sampling}

The seasonal changes in the populations of leaves on the most suitable sampling parts of jackfruit are showed in Figure 1. From the graph, we know that the leaf nutrient concentrations of $\mathrm{K}$ and $\mathrm{Cu}$ are both increase during spring and summer, and then show a large fluctuation but no clear trends; The concentration levels of Ca, $\mathrm{Zn}$ and B increase during springtime, and then slightly decrease; The concentration levels of P, Mg and S are relatively constant throughout the year; The concentration of $\mathrm{N}$ is the highest (3.18\%) in December, and then drop; The maximum content of Fe $\left(127.48 \mathrm{mg} \cdot \mathrm{kg}^{-1}\right)$ is in January, and then tend to decline until October; The maximum accumulation of $\mathrm{Mn}$ is in February, and then fall until May followed by a gradual rise until September. The results demonstrated that the stability of leaf nutrient concentrations in the jackfruit was from April to May.

\subsection{The Standard of Leaf Nutrient Concentrations}

The leaves were sampled in the 3 - 6 month-old leaves from the central canopy between April and May of 2011-2013. The mean and range of jackfruit leaf nutrient concentrations is shown in Table 2. As can be seen from the data of the range of leaf nutrient concentrations, the leaf nutrient status in different jackfruit orchard varied differently. Compared to the leaf macronutrient (N, P, K, Ca, Mg, S) concentrations range, the leaf micronutrient (Fe, Mn, Cu, Zn, B) concentrations are more wide range. The standard of leaf nutrient concentrations is shown in Table 3. The optimum range of $\mathrm{N}, \mathrm{P}, \mathrm{K}, \mathrm{Ca}, \mathrm{Mg}, \mathrm{S}, \mathrm{Fe}, \mathrm{Mn}, \mathrm{Cu}, \mathrm{Zn}$ and $\mathrm{B}$ is obtained. Below the optimum range is considered as hidden hunger or severely deficient, and above the optimum range is considered as luxury absorption or excessive toxicity.

\section{Discussion}

In this study, we found that the stability of leaf nutrient concentrations in the jackfruit was in the 3 - 6 month-old leaves from the central canopy between April and May. Sampling parts, which the nutrient concentrations approximated to the average of the whole plant, could be used as the most suitable sampling parts [9] [13] [14] [16]. Therefore, in the study of bael leaf sampling technique, 6 - 7 month-old leaves were stability for the evaluation of $\mathrm{N}, \mathrm{P}$ and $\mathrm{K}$, whereas in this study, the 3 - 6 month-old leaves from the central canopy may be most suitable to develop foliar nutrient standards for jackfruit. Additionally, the young leaf nutrient concentrations are unstable because of their in the stage of continued growth, so the leaves were not sampled, and the nutrients over 6 month-old leaves may be transferred or accumulated, so the leaves were also not suitable for sampling. Some other researches indicated that there were significant differences in leaf nutrient concentrations among four di- 

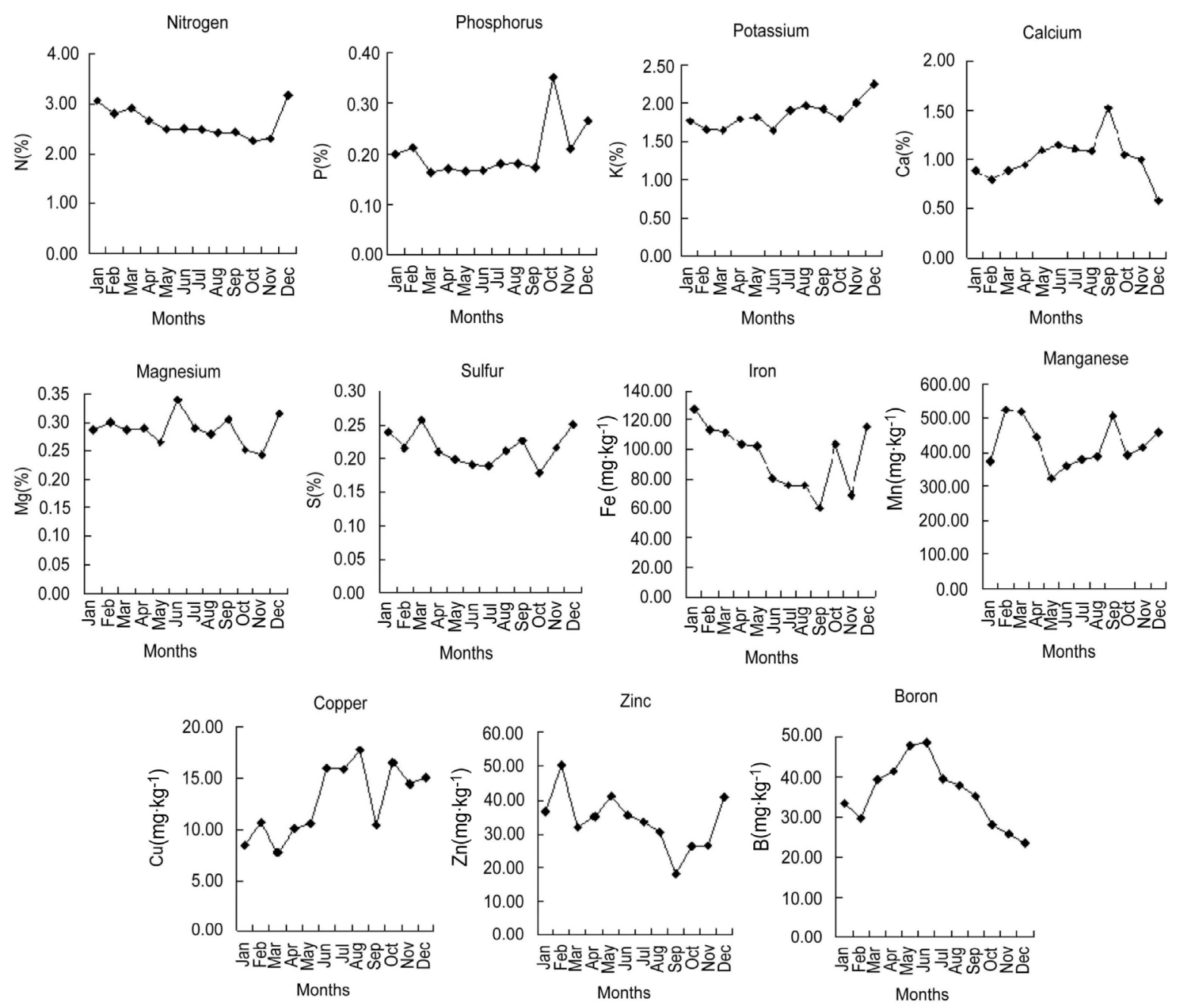

Figure 1. Changes in leaf nutrient concentrations of jackfruit during annual growth cycle of 2011-2013.

Table 2. The mean and range of leaf nutrient concentrations of jackfruit.

\begin{tabular}{|c|c|c|c|c|c|c|c|c|c|c|c|}
\hline \multirow{2}{*}{ Nutrient } & \multicolumn{6}{|c|}{ Macronutrient (\%) } & \multicolumn{5}{|c|}{ Micronutrient $\left(\mathrm{mg} \cdot \mathrm{kg}^{-1}\right)$} \\
\hline & $\mathrm{N}$ & $\mathrm{P}$ & K & $\mathrm{Ca}$ & $\mathrm{Mg}$ & S & $\mathrm{Fe}$ & Mn & $\mathrm{Cu}$ & $\mathrm{Zn}$ & B \\
\hline Mean & 2.59 & 0.17 & 1.81 & 1.03 & 0.28 & 0.20 & 102.72 & 384.83 & 10.35 & 38.30 & 44.65 \\
\hline Min & 2.35 & 0.15 & 1.19 & 0.80 & 0.16 & 0.18 & 84.58 & 184.53 & 5.99 & 32.17 & 36.65 \\
\hline Max & 2.73 & 0.18 & 2.08 & 1.38 & 0.42 & 0.22 & 117.83 & 505.78 & 15.29 & 44.77 & 59.24 \\
\hline SD & 0.13 & 0.01 & 0.32 & 0.21 & 0.10 & 0.02 & 10.70 & 108.84 & 3.04 & 4.18 & 7.96 \\
\hline
\end{tabular}

Data are based on 30 samples.

rections of the same canopy [13], accordingly, sampled from different direction may lead to wrong result. Therefore, further works are needed to resolve this untouched problem.

Time of sampling, which the nutrient concentrations approximated to the annual average, could be used as the most suitable sampling time [6] [10] [13] [14] [16]. Therefore, in the study of olive leaf sampling technique, the wintertime was stability for the evaluation of $\mathrm{N}$, whereas in this study, the period from April to May may be most suitable to develop foliar nutrient standards for jackfruit. In addition, the jackfruit ripening period is from June to July, and the best time for fertilization is after harvest. For a better growth in the following year, the jackfruit nutritional status was evaluated between April and May. Subsequently, the best fertilizer programs can be planned. 
Table 3. The standard of leaf nutrient concentrations of jackfruit for getting optimum yield.

\begin{tabular}{cccccc}
\hline Nutrient & Deficiency & Low & Optimum & High & Excess \\
\hline $\mathrm{N}(\%)$ & $<2.24$ & $2.24-2.41$ & $2.42-2.76$ & $2.77-2.94$ & $>2.94$ \\
$\mathrm{P}(\%)$ & $<0.14$ & $0.14-0.15$ & $0.16-0.18$ & $0.19-0.20$ & $>0.20$ \\
$\mathrm{~K}(\%)$ & $<0.96$ & $0.96-1.37$ & $1.38-2.24$ & $2.25-2.66$ & $>2.66$ \\
$\mathrm{Ca}(\%)$ & $<0.47$ & $0.47-0.74$ & $0.75-1.31$ & $1.32-1.59$ & $>1.59$ \\
$\mathrm{Mg}(\%)$ & $<0.01$ & $0.01-0.14$ & $0.15-0.41$ & $0.42-0.55$ & $>0.55$ \\
$\mathrm{~S}(\%)$ & $<0.15$ & $0.15-0.16$ & $0.17-0.23$ & $0.24-0.25$ & $>0.25$ \\
$\mathrm{Fe}\left(\mathrm{mg} \cdot \mathrm{kg}^{-1}\right)$ & $<74.19$ & $74.19-88.44$ & $88.45-116.99$ & $117.00-131.25$ & $>131.25$ \\
$\mathrm{Mn}\left(\mathrm{mg} \cdot \mathrm{kg}^{-1}\right)$ & $<94.59$ & $94.59-239.70$ & $239.71-529.95$ & $529.96-675.07$ & $>675.07$ \\
$\mathrm{Cu}\left(\mathrm{mg} \cdot \mathrm{kg}^{-1}\right)$ & $<2.24$ & $2.24-6.29$ & $6.30-14.40$ & $14.41-18.46$ & $>18.46$ \\
$\mathrm{Zn}\left(\mathrm{mg} \cdot \mathrm{kg}^{-1}\right)$ & $<27.15$ & $27.15-32.72$ & $32.73-43.87$ & $43.88-49.45$ & $>49.45$ \\
$\mathrm{~B}\left(\mathrm{mg} \cdot \mathrm{kg}^{-1}\right)$ & $<23.42$ & $23.42-34.03$ & $34.04-55.26$ & $55.27-65.88$ & $>65.88$ \\
\hline
\end{tabular}

The standard of leaf nutrient concentrations consist of deficient range, low range, optimum range, high range and excess range for each nutrient, and it may be used as the standard of nutrient suitability evaluation. However, the availability of fertilizers is closely related to soil nutrient supplying power and plant nutrient absorption capacity, therefore, how to fertilize the jackfruit in the condition of below or above the optimum range is needed further research.

\section{Conclusion}

For the evaluation of jackfruit nutritional status, this study has determined the jackfruit sampling technique, including the canopy height, leaf age and time of sampling. The stable intra-canopy of leaf sampling was the 3 - 6 month-old leaves from the central canopy, and the stable period of leaf sampling was between April and May. Also, this study has determined the standard of suitable leaf nutrient concentrations. Our work continues for 3 years, and the obtained data provide a basis of reference standards for jackfruit leaf nutrient analysis. The results of the paper may be used for jackfruit nutrient status diagnosis and helping to plan fertilizer programs.

\section{Acknowledgements}

The authors are grateful to Dr. Qimin Cao for the suggestions of this manuscript and thank Dr. Ningning Cheng for his technical assistance.

\section{References}

[1] Baldock, J.O. and Schulte, E.E. (1996) Plant Analysis with Standardized Scores Combines DRIS and Sufficiency Range Approaches for Corn. Agronomy Journal, 88, 448-456. http://dx.doi.org/10.2134/agronj1996.00021962008800030015x

[2] Bell, R.W. (2000) Temporary Nutrient Deficiency, a Difficult Case for Diagnosis and Prognosis by Plant Analysis. Communications in Soil Science and Plant Analysis, 31, 11-14. http://dx.doi.org/10.1080/00103620009370542

[3] Cline, R.A. (1990) Thirty Years of Diagnosing Nutritional Status of Deciduous Orchards and Vineyards by Leaf Analyses in Ontario, Canada. Acta Horticulturae, 274, 107-112.

[4] Lamb, D. (1976) Variations in the Foliar Concentrations of Macro and Micro Elements in a Fast-Growing Tropical Eucalypt. Plant and Soil, 45, 477-492. http://dx.doi.org/10.1007/BF00011708

[5] Tagliavini, M., Scudellari, D., Marangoni, B., Bastianel, A., Franzin, F. and Zamborlini, M. (1992) Leaf Mineral Composition of Apple Tree: Sampling Date and Effects of Cultivar and Rootstock. Journal of Plant Nutrition, 15, 605619. http://dx.doi.org/10.1080/01904169209364344

[6] Zatylny, A.M. and St-Pierre, R.G. (2006) Development of Standard Concentrations of Foliar Nutrients for Saskatoon. Journal of Plant Nutrition, 29, 195-207. http://dx.doi.org/10.1080/01904160500468662

[7] Jones, J.B. (1985) Soil Testing and Plant Analysis: Guides to the Fertilization of Horticultural Crops. Horticultural Reviews, 7, 1-68.

[8] Jones Jr., J.B., Wolf, B. and Mills, H.A. (1991) Plant Analysis Handbook: A Practical Sampling, Preparation, Analysis, 
and Interpretation Guide. Micro-Macro Publishing, Athens.

[9] Awasthi, O.P., Pathak, R.A. and Pathak, R.K. (1993) Effect of Age and Position of Shoot on Mineral Composition of Aonla. Indian Journal of Horticulture, 50, 134-138.

[10] Bell, D.T. and Ward, S.C. (1984b) Seasonal Changes in Foliar Macro-Nutrients (N, P, K, Ca, Mg) in Eucalyptus saligna Sm. and E. wandoo Blakely Growing in Rehabilitated Bauxite Mine Soils of the Darling Range, Western Australia. Plant and Soil, 81, 377-388. http://dx.doi.org/10.1007/BF02323052

[11] Escudero, A., Del Arco, J.M., Sanz, I.C. and Ayala, J. (1992) Effects of Leaf Longevity and Retranslocation Efficiency on the Retention Time of Nutrients in the Leaf Biomass of Different Woody Species. Oecologia, 90, 80-87. http://dx.doi.org/10.1007/BF00317812

[12] Guha, M.M. and Mitchell, R.L. (1965) The Trace and Major Element Composition of the Leaves of Some Deciduous Trees. Plant and Soil, 23, 323-338. http://dx.doi.org/10.1007/BF01347727

[13] Perica, S. (2001) Seasonal Fluctuation and Intracanopy Variation in Leaf Nitrogen Level in Olive. Journal of Plant Nutrition, 24, 779-787. http://dx.doi.org/10.1081/PLN-100103670

[14] Dhandhar, D.G. and Bhargava, B.S. (1993) Leaf Sampling Technique for Nutritional Diagnosis in Custard Apple. Indian Journal of Horticulture, 50, 1-4.

[15] Kamboj, J.S., Dhatt, A.S. and Grewal, G.P.S. (1995) Leaf Analysis as a Guide to Diagnosis of Nutritional Status of Sub-Tropical Pear. Acta Horticulturae, 383, 367-375.

[16] Mahesh, K. and Singh, A.K. (2005) Standardization of Leaf Sampling Technique in Bael. Communications in Soil Science and Plant Analysis, 36, 2153-2164. http://dx.doi.org/10.1080/00103620500196093

[17] Singh, H.P., Chadha, K.L. and Bhargava, B.S. (1990) Leaf Sampling Technique in Acid Lime (Citrus aurantifolia Swingle) for Nutritional Diagnosis. Indian Journal of Horticulture, 47, 133-139.

[18] Anjaneyulu, K. (2007) Diagnostic Petiole Nutrient Norms and Identification of Yield Limiting Nutrients in Papaya (Carica papaya) Using Diagnosis and Recommendation Integrated System. Indian Journal of Agricultural Sciences, 77, 3-6. 
Scientific Research Publishing (SCIRP) is one of the largest Open Access journal publishers. It is currently publishing more than 200 open access, online, peer-reviewed journals covering a wide range of academic disciplines. SCIRP serves the worldwide academic communities and contributes to the progress and application of science with its publication.

Other selected journals from SCIRP are listed as below. Submit your manuscript to us via either submit@scirp.org or Online Submission Portal.
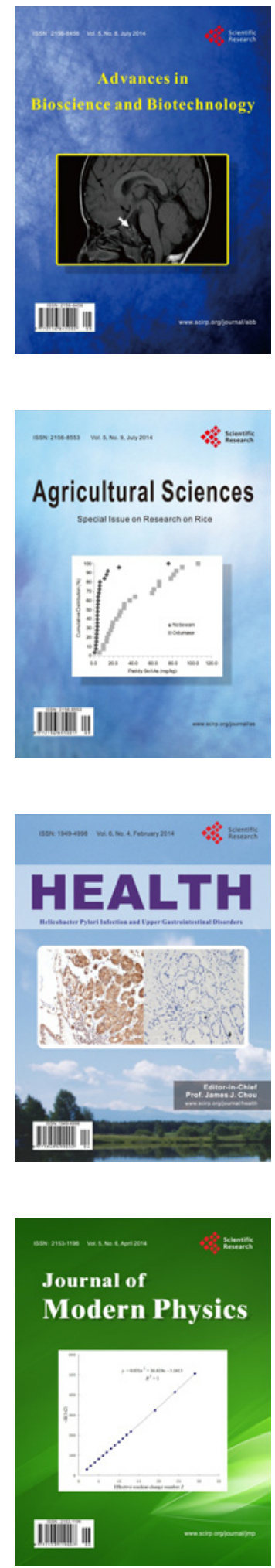
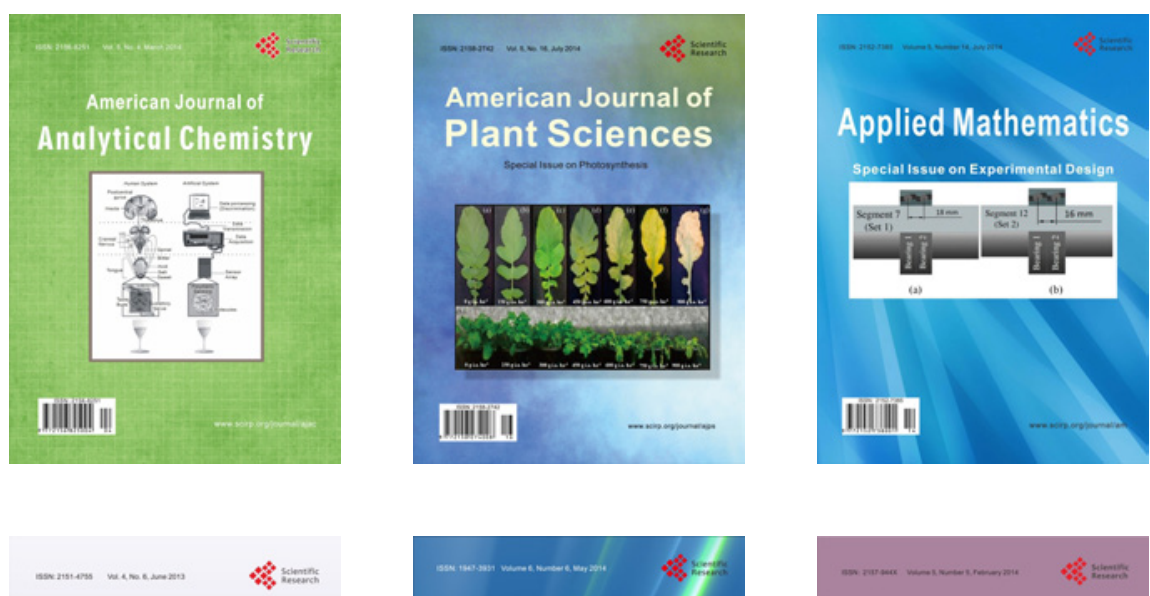

Creative Education
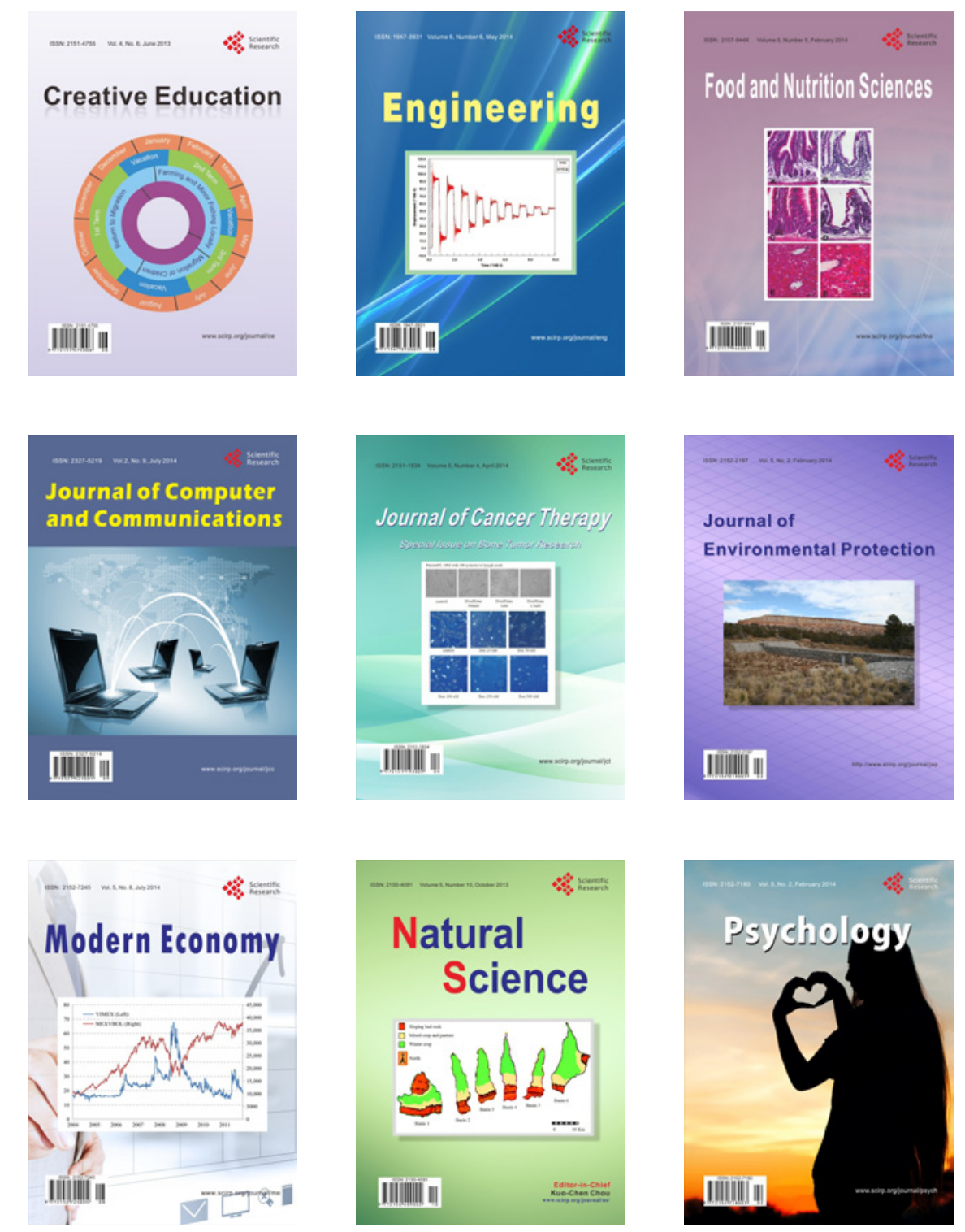